\title{
Strawberry mild yellow edge potexvirus from Strawberry in Korea
}

\author{
Jeom-Deog Cho ${ }^{1}$, Gug-Seoun Choi ${ }^{1}$, Bong-Nam Chung ${ }^{1}$, Jeong-Soo Kim ${ }^{2 *}$ and Hong-Soo Choi ${ }^{2}$ \\ ${ }^{I}$ National Institute of Horticulture and Herbal Science, RDA, Suwon 441-440, Korea \\ ${ }^{2}$ National Academy of Agricultural Science, RDA, Suwon 441-707, Korea \\ (Received on March 23, 2011; Accepted on April 25, 2011)
}

\begin{abstract}
Symptoms induced in the leaves of strawberry (Fragaria $x$ ananassa Duch.), 'Seolhyang' and 'Eyeberry', were mosaic, distortion and black colored edge on leaves at Nonsan area, one of the important production areas in Korea. Electron microscopy by quick-dip revealed the flexuous rod-shape particles having about 550-600 $\mathrm{nm}$ length. Cytoplasmic inclusion bodies composed of aggregated virus particles were observed frequently in mesophyll parenchyma and epidermal cells for the leaves of strawberry. The specific primers amplifying products of $635 \mathrm{bp}$ and $729 \mathrm{bp}$ were developed for RT-PCR detection of Strawberry mild yellow edge virus (SMYEV). Nucleotide identity of the CP gene of SMYEV was 92.8$\mathbf{9 9 . 2 \%}$ with those of other SMYEV isolates from GenBank database.
\end{abstract}

Keywords : nucleotide identity, RT-PCR, SMYEV, strawberry, ultrastructure

Strawberry, the genus Fragaria, is one of the fruit vegetables producing about 200 metric tons for the five years from 2001 in Korea (naqs.go.kr/statistics). The Korean consumption of strawberry is shared to $6 \%$ of world and $13 \%$ of Europe production (Babini et al., 2004). More than 30 kinds of virus are known to infect strawberry, but the symptoms are not described well. Viral infection in strawberry may cause stunting under continuous cropping and a loss of vigor, and resulted up to $80 \%$ yield loss from the synergistic symptom expression with the mixed infection of two or more viruses. The disease by Strawberry mild yellow edge virus (SMYEV) was first described in California in 1922 and it has occurred with an infection rate of over 30\% (Converse et al., 1987).

SMYEV is transmitted by the strawberry aphid in a persistent manner. Five European countries including Italy, three aphid-transmitted viruses, Strawberry mild yellow edge virus (SMYEV), Strawberry mottle virus (SMoV) and Strawberry crinkle virus (SCV) without Strawberry vein

\footnotetext{
*Corresponding author.

Phone) +82-31-290-0430, FAX) +82-31-290-0434

E-mail)kimjsoo@korea.kr
}

banding virus (SVBV) occurred with the infection rate of $1.3 \%, 1.6 \%$ and $1.2 \%$, respectively, and SMoV occurred only regionally in Poland and Lithuania (Babini et al., 2004; Karesova et al., 2004). The viral infection can be determined by the diagnostic methods of bioassay, serological test of ELISA and genetic test of RT-PCR. The bioassay using indicator plants by grafting has been used classically. The ELISA and RT-PCR have been developed recently against strawberry infecting viruses (Thompson and Jelkmann, 2004a), but those methods need to be verified for the purpose of certification or quarantine in the world (Martin, 2004). The multiplex RT-PCR for the 4 aphid transmitting viruses was proposed (Thompson, Wittzel and Jelkmann, 2004), however, three viruses (SCV, SMYEV and $\mathrm{SMoV}$ ) could be detected in every possible combination, excluding with SVBV. In Korea, there is no report for the viruses infecting strawberry to date in spite of mass production of strawberry fruits from the mass multiplication of strawberry clones.

Strawberry cultivar 'Seolhyang' was collected from Nonsan area and 'Eyeberry' cultivar was acquired at greenhouse maintaining genetic resources in Nonsan strawberry experiments station. Mosaic symptom was produced typically on the newly developed leaves of strawberry 'Seolhyang' (Fig. 1). The leaves showing mosaic symptom were developed distortion later. On 'Eyeberry' cultivar of strawberry, the typical symptom of black colored edge on the leaves was produced.

Electron microscopy was conducted through LEO 902A. Quick leaf dip method was used for the observation of virus particles after staining with $2 \%$ PTA. Potexvirus particles of flexuous rod having 550-600 nm length were observed frequently from the leaves of strawberry showing the symptoms of mosaic, distortion and black leaf margin (Fig. 2). For the ultrastructural studies of the infected cells, the leaves of strawberry were cut into $1 \times 1-2 \mathrm{~mm}$ and fixed with Karnovsky's fixative for $30 \mathrm{~min}$. The fixed specimens were dehydrated with ethyl alcohol gradually from $30 \%$ to $100 \%$ with 8 steps. For infiltration medium of the dehydrated specimens, LR White resin was used. Hardening of the resin blocks was done at 60 for $24 \mathrm{hr}$. Sections of $80 \mathrm{~nm}$ thickness were stained with uranyl acetate and lead citrate 

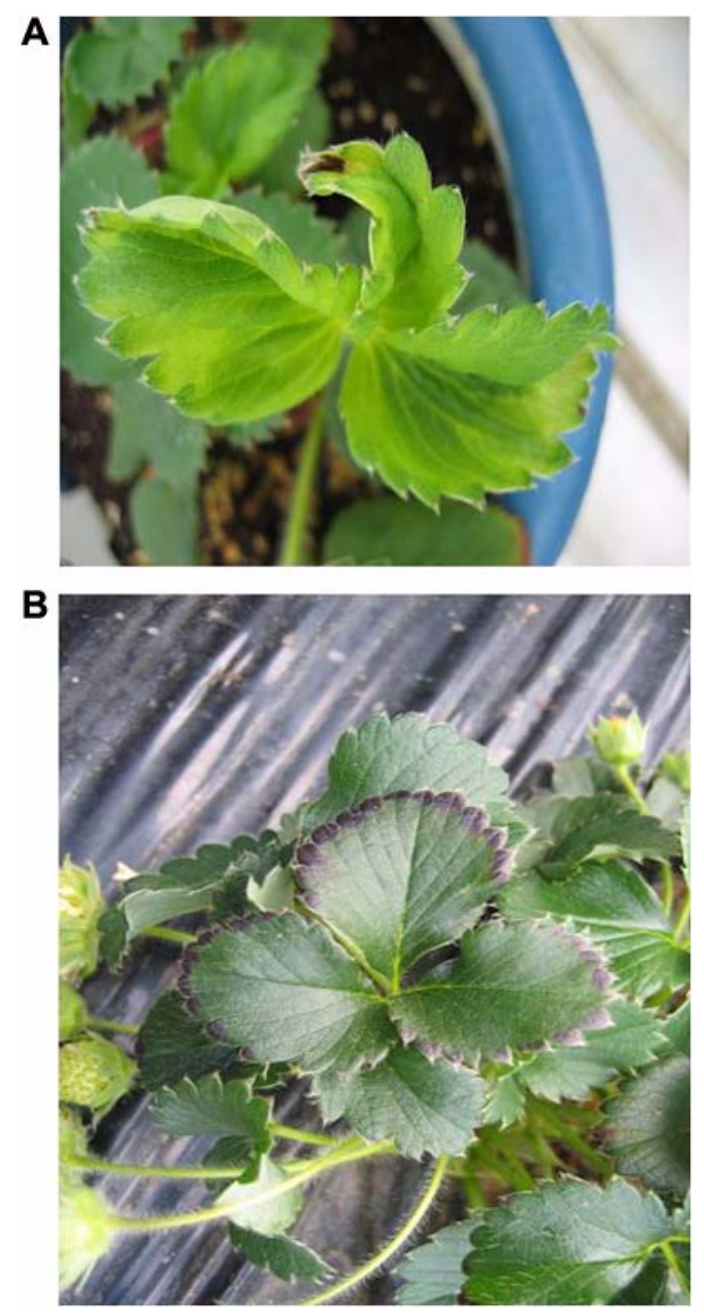

Fig. 1. Symptoms of mosaic and distortion induced on the newly developed leaf of strawberry 'Seolhyang' (A). The black edge (B) on the leaf of strawberry 'Eyeberry' developed more severe by plant growth.

for $2 \mathrm{~min}$ and $10 \mathrm{~min}$, respectively. The flexuous rod virus particles of SMYEV sectioned longitudinally were presented in a mass in epidermal cells (Fig. 3). The mass of virus particles was a typical inclusion body induced by the Potexvirus including SMYEV. SMYEV presented mainly in the epidermal cells. The virus particles of SMYEV were scattered heavily in the cytoplasm of parenchyma cells. No virus bands formed typically by Potexvirus were observed (Francki et al., 2000). The scattered virus particles were associated with the amorphous protein bodies which were considered as new ultrastructures related closely with SMYEV (Fig. 4). The amorphous protein bodies might be thought as a viroplasm associated with the multiplication of SMYEV. SMYEV could replicate well and abundantly in the cells of strawberry 'Seolhyang'.

Sample of the infected leaf was ground in liquid nitrogen with mortar and pestle. According to manual for NucliSens ${ }^{\mathbb{\circledR}}$,

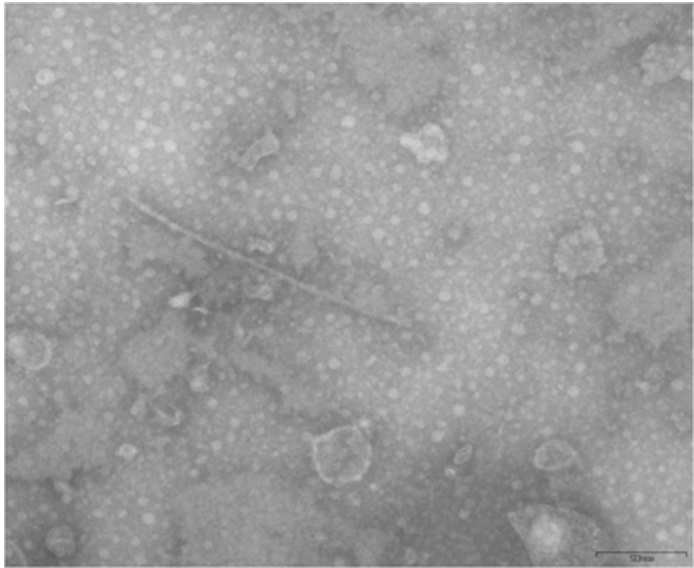

Fig. 2. Flexuous rod virus particle having the length of 550-600 $\mathrm{nm}$ obsereved by Quick dip electron microscopy of the leaves of strawberry.
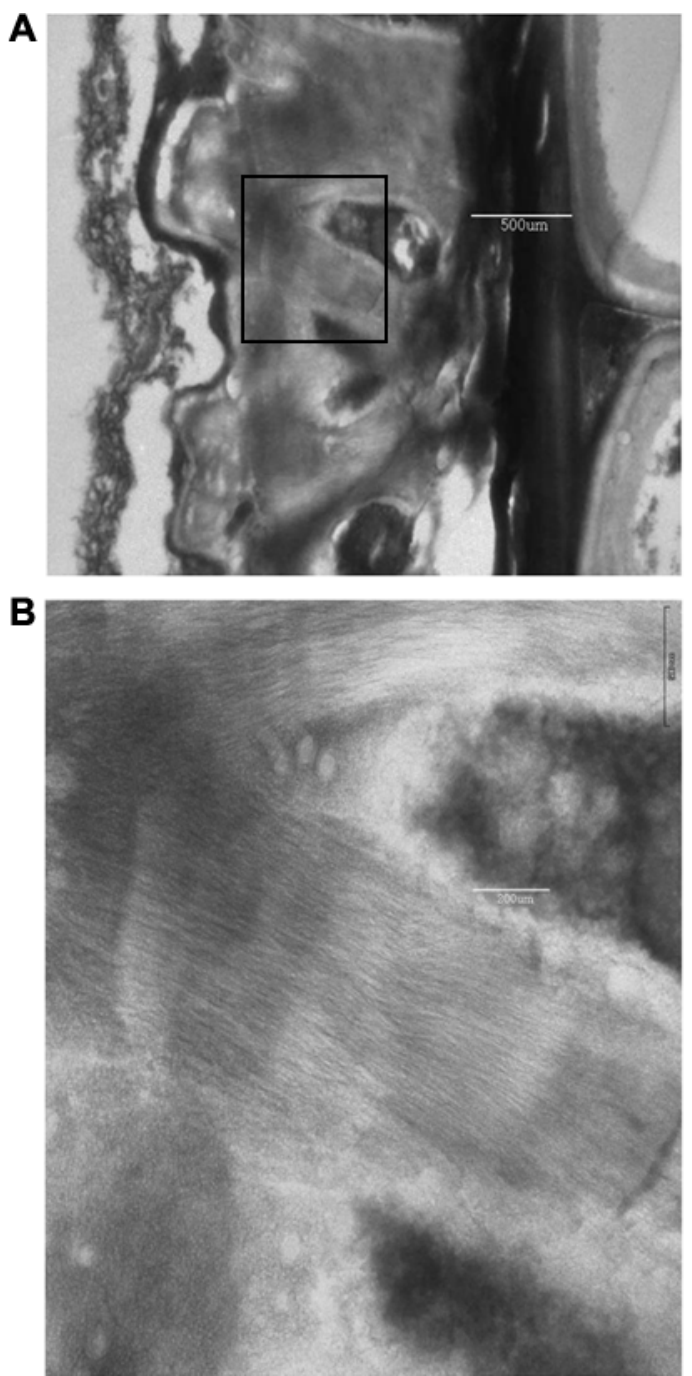

Fig. 3. The virus particles of SMYEV were compacted as a typical inclusion body in epidermal cells. The image was enlarged from the area outlined in the figure A. 

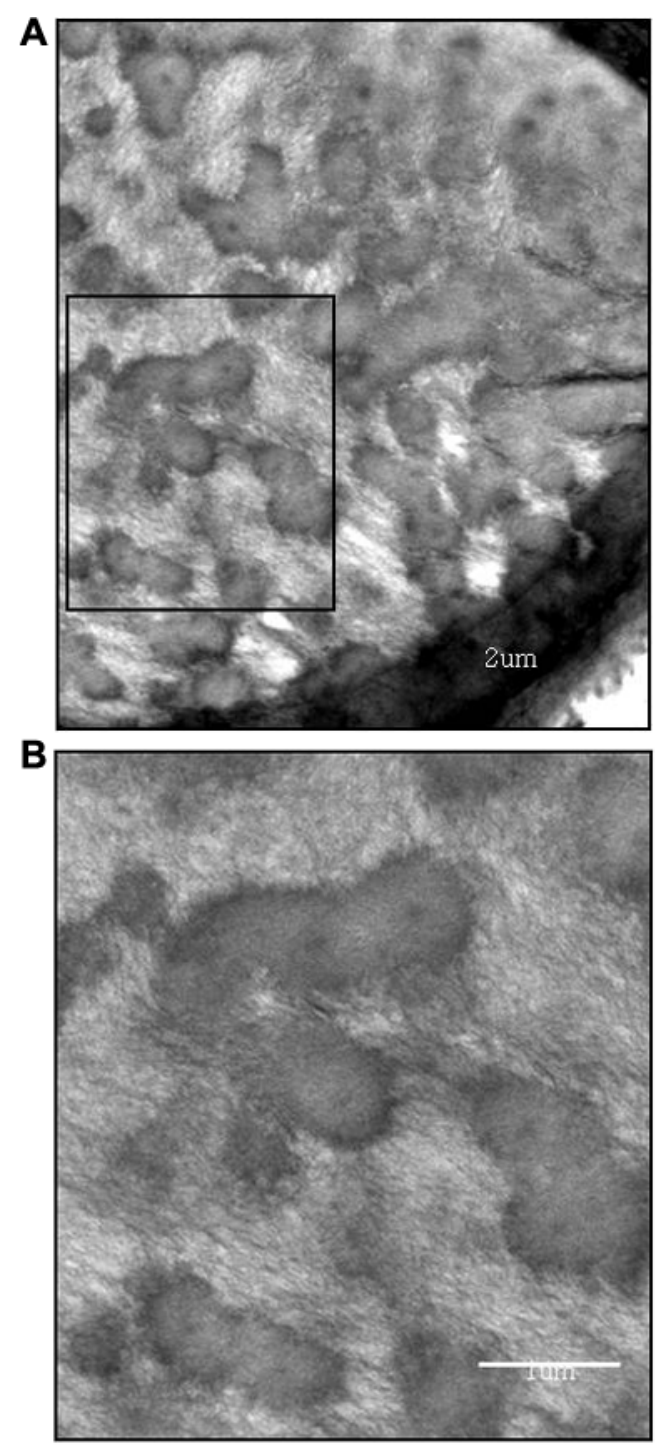

Fig. 4. The virus particles of SMYEV sectioned longitudinally in a parenchyma cell associated intimately with the proteinaceous bodies. The amorphous electron dense materials enlarged the rectangular figure $\mathrm{A}$.

silica solution of $50 \mu \mathrm{l}$ was added in $1 \mathrm{~g}$ ground tissue and dried for $2 \mathrm{~min}$ at $56^{\circ} \mathrm{C}$. The silica particles were washed with shift $70 \%$ ethanol and $99.9 \%$ acetone for three times by air flow. Total RNA was collected by elution with Nuclease-free water. All procedures were done automatically with NucliSens Extractor made by Biomerieux corporate. The primers for the PCR diagnosis of SMYEV were designed as follows; SMYEV CPF: 5'-ATC CAT TGC CAA TGG GCT-3, SMYEV CPR: 5'-TCC TTT AGT CAG GAG CGT-3', which made the 635 base pair product for part of coat protein. Primers for full length coat protein was SMYEV FPF: 5'-ACA ATC GCY CTG GTC AGT AA-3', SMYEV FPR: 5'-GCT GGG TAG AAG AAG TGA GA3', which produced the 729 base pair product. Primers were
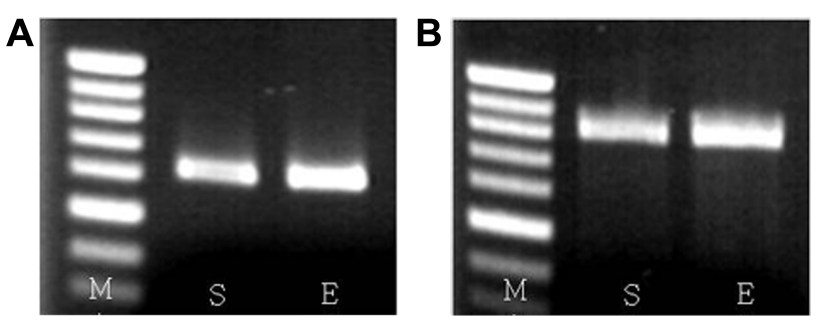

Fig. 5. RT-PCR of SMYEV with the primers amplifying a product of $635 \mathrm{bp}$ (Left) and the primer for full sequence of coat protein gene of $729 \mathrm{bp}$ (Right); M, Marker from $0.3-1.0 \mathrm{~kb}$ by 0.1 ladder; S, 'Seolhyung'; E, 'Eyeberry'

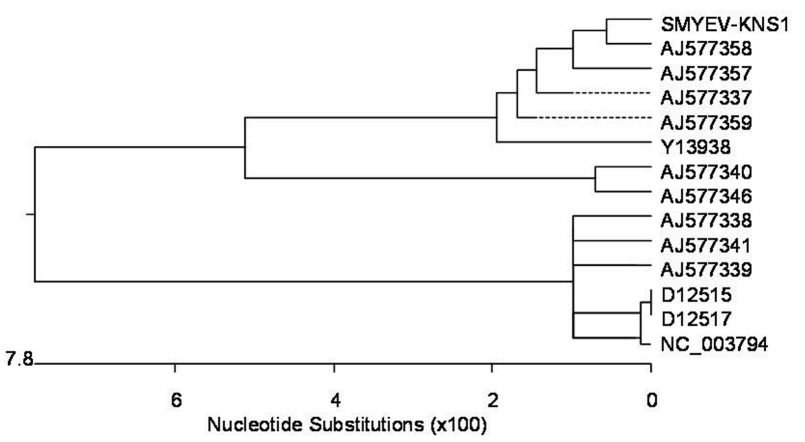

Fig. 6. Phylogenetic analysis of SMYEV-KNS1 with 13 isolates of SMYEV in the NCBI data base. The 14 isolates were classified into two subgroups by nucleic acid differences within $7.8 \%$.

designed with DNASTAR lagergene 7 using reported sequences available from NCBI GenBank. cDNA amplification was conducted with AccessQuick ${ }^{\mathrm{TM}}$ RT-PCR System (Promega). RT-PCR thermo-profile was conducted firstly by reverse transcription at $48^{\circ} \mathrm{C}$ for $1 \mathrm{hr}$, followed by 40 cycles as $94^{\circ} \mathrm{C}$ for $2 \mathrm{~min}, 51^{\circ} \mathrm{C}$ for $30 \mathrm{sec}$ and $72^{\circ} \mathrm{C}$ for 2 $\mathrm{min}$, and final elongation at $72^{\circ} \mathrm{C}$ for $10 \mathrm{~min}$. Cleanup of products from the RT-PCR amplification was done with QIAquick ${ }^{\circledR}$ PCR purification kit (QIAGEN). The purified cDNAs were cloned in pGEM-T easy vector (Promega) and transformation into Escherichia coli JM109. The sequences were compared with other SMYEV RNA sequences in GenBank (Fig. 6) using MecAlign in DNASTAR lagergene 7 engene.

SMYEV was detected effectively by the two kinds of specific primers for $635 \mathrm{bp}$ and $729 \mathrm{bp}$ (Fig. 5). Total RNA could be extracted effectively by the Silica based Nuclisens for the PCR detection of SMYEV from the leaves of strawberry 'Soelhyang' showing mosaic and distortion, and 'Eyeberry' showing black edge. SMYEV-KNS1 isolated from strawberry 'Seolhyung' had nucleotide identity around 99\% to SMYEV-WSU1988 (AJ577358.1) and SMYEVIndukaB (AJ577357.1). However, SMYEV-KNS1 was differed by $7.8 \%$ from 7 isolates of SMYEV including SMYEV-2CH (AJ577338.1). The 14 isolates of SMYEV 
reported in the worlds could be classified genetically into two groups. The 23 isolates of SMYEV had nucleotide sequence identities varying from $84.6 \%$ to $100 \%$, and they were classified into 3 subgroups genetically (Jelkmann and Thompson, 2004a). The Korean isolate, however, was compared to representative sequences from each of the three subgroups identified by Thompson and Jelkmann. Based on the RNA encoding coat protein, the 14 isolates were classified into two subgroups by nucleic acid differences within $7.8 \%$ (Fig. 6). The virulence of SMYEV will be studied continuously in future as the strains of SMYEV may develop depending upon the cropping areas and/or the cultivars of strawberry.

\section{References}

Babini, A. R., Cislinska, M., Karesova R., Thompson, J. R. and Cardon. 2004. Occurrence and identification of strawberry viruses in five European countries. Acta Horticulturae No. 656:39-43.

Converse, R. H., Martin, R. R. and Siegel, S. 1987. Strawberry mild yellow edge. USDA Agricultural Handbook. Virus Disease of Small Fruit: 25-29.

Francki, R. I. B., Milne, R. G. and Hatta, T. 2000. Potexvirus group; In Atlas of plant viruses Vol.II CRC Press, Inc. pp. 159172.

Karesova, R., Vackova, H. and Paprstein, F. 2004. Invetigation of occurrence and testing of aphid-borne strawberry viruses. Acta Horticulturae No. 656:63-67.

Martin, R. R. 2004. Recommended procedures for detection of viruses of small fruit crops. Acta Horticulturae No. 656:199207.

Thompson, J. R. and Jelkmann, W. 2004a. Strain diversity and conserved genome elements in Strawberry mild yellow edge virus. Arch Virol 149:1897-1909.

Thompson, J. R. and Jelkmann, W. 2004b. Variation in the coat protein of Strawberry mild yellow edge virus and the complete sequence of aphid transmissible strain D-74. Acta Horticulturae No. 656:57-62.

Thompson, J. R., Wttzel, S. and Jelkmann, W. 2004. Pentaplex RT-PCR for the simultaneous detection of four aphid-borne viruses in combination with a plant mRNA specific internal control in Fragaria. Acta Horticulturae No. 656:51-56. 